\title{
Plant-based frozen desserts: temporal sensory profile and preference
}

\section{Gelados comestíveis plant-based: perfil sensorial temporal e preferência}

\author{
Alessandra Cazelatto de Medeiros ${ }^{1 *}$ (i), Helena Maria André Bolini ${ }^{1}$ (i) \\ ${ }^{1}$ Universidade Estadual de Campinas (UNICAMP), Faculdade de Engenharia de Alimentos (FEA), Campinas/SP - \\ Brasil \\ ${ }^{*}$ Corresponding Author: Alessandra Cazelatto de Medeiros, Universidade Estadual de Campinas (UNICAMP), \\ Faculdade de Engenharia de Alimentos (FEA), Rua Monteiro Lobato, 80, CEP: 13083-862, Campinas/SP - Brasil, \\ e-mail:acmls@unicamp.br
}

Cite as: Medeiros, A. C., \& Bolini, H. M. A. (2021). Plant-based frozen desserts: temporal sensory profile and preference. Brazilian Journal of Food Technology, 24, e2020037. https://doi.org/10.1590/1981-6723.03720

\begin{abstract}
To respond to the growing demand for specific diets aimed at lactose intolerant and vegan consumers, chocolateflavored frozen desserts with no addition of lactose and other animal-derived products were produced, and the temporal profile and the consumers' acceptance of the samples with sucrose substitution by sweeteners were also investigated. Six frozen dessert formulations were made, three made with soy protein and three with rice protein, sweetened with sucrose, sucralose, and stevia. Acceptance tests and Time-Intensity (TI) analysis were performed to assess the intensity and duration of the attributes sweet taste, bitter taste, chocolate flavor, and melting behavior. The results showed no effect of the different plant proteins on the temporal profile and the acceptance by consumers. The use of sweeteners altered the temporal sensory profile and negatively impacted the acceptance of the samples. The sucralose-sweetened formulations were characterized by a lower intensity of sweet taste, chocolate flavor, and bitterness, whereas the stevia-sweetened formulations showed greater intensity and duration of the bitter taste. Characteristics such as the low intensity of chocolate flavor and the increase in sweetness affected the final acceptance of the product. The melting time of frozen desserts has been extended with the use of body agents to replace sucrose.
\end{abstract}

Keywords: Time-intensity analysis; Penalty analysis; Plant-based; Frozen desserts; Sweeteners; Drivers of liking.

\section{Resumo}

A fim de atender à demanda de dietas específicas, destinadas a intolerantes à lactose e consumidores veganos, o estudo teve como objetivo formular gelados comestíveis sabor de chocolate sem adição de lactose e outros produtos de origem animal, além de caracterizar o perfil temporal das amostras com substituição de sacarose por edulcorantes e avaliar a aceitação por consumidores. Foram formuladas seis amostras de gelados comestíveis, sendo três com proteínas de soja e três com proteína de arroz, adoçadas com sacarose, sucralose e estévia. Foram realizadas análises de aceitação e Tempo-Intensidade para avaliação de intensidade e duração dos atributos gosto doce, gosto amargo, sabor de chocolate e derretimento. Os resultados mostraram que a utilização das diferentes proteínas vegetais não interferiu no perfil sensorial temporal e na aceitação pelos consumidores. A utilização de 
edulcorantes alterou o perfil sensorial temporal e impactou negativamente na aceitação das amostras, sendo as amostras adoçadas com sucralose caracterizadas pela menor intensidade de gosto doce, sabor de chocolate e amargor, enquanto as formulações com estévia apresentaram maior intensidade e duração do gosto amargo. Características como a baixa intensidade de sabor de chocolate e o aumento na doçura tiveram influência na aceitação final do produto. O tempo de derretimento dos sorvetes foi prolongado com a utilização de agentes de corpo na substituição de sacarose.

Palavras-chave: Análise tempo-intensidade; Análise de penalidade; Plant-based; Gelados comestíveis; Edulcorantes; Direcionadores de preferência.

\section{Introduction}

The interest in veganism has increased worldwide, ranging from 1 to $5 \%$ of the population that consume plant-based meals in several countries such as the United States of America (USA) (2\%), Israel (5\%), United Kingdom (UK) (2\%), Australia (1\%), and Germany (1\%) (Radnitz et al., 2015). Veganism is a diet and lifestyle choice that avoids the consumption of all animal products, including meat, dairy products, eggs, honey, and other products (Cramer et al., 2017). There are other diets with variations in these restrictions, such as strict vegetarianism, which avoids the consumption of animal-derived foods (Animal Source Foods (ASF)), including dairy products (Craig \& Mangels, 2016). There are several reasons for the practice of veganism, including moral, ethical, spiritual, and religious aspects, animal welfare, sensory preferences, lifestyle, dietary restrictions, and the search for improvements in health, with emphasis on issues related to health and ethics (Fox \& Ward, 2008; Ruby, 2012; Dyett et al., 2013).

In this scenario, products made with plant-based proteins may be an alternative for the replacement of bovine milk in the treatment of allergies, lactose intolerance, and in the vegan diet. However, despite their high nutritional and functional potential, foods containing soy and rice derivatives are not well accepted by consumers due to the unpleasant flavor from the compounds present in the grain or formed during processing (Assumpção, 2008; Casé et al., 2005; Miyamoto \& Auler, 2008). These undesirable attributes can be minimized with the use of plant-based protein isolates, which contain at least $90 \%$ of protein and are considered a versatile alternative to improve the organoleptic characteristics and the nutritional values of food (Tseng et al., 2009), in addition to having specific functional properties (Hagenimana et al., 2007).

The growing demand for products intended for specific diets, with no harmful compounds (Crizel et al., 2014) and characteristics similar to traditional foods (Cruz et al., 2009) makes the ice cream an attractive alternative, containing ingredients with nutritional and physiological properties (Aboulfazli et al., 2016). Ice cream has high consumers' acceptability, being a highly consumed product worldwide, with a great consumption demand in cold climate countries such as New Zealand, Canada, and Australia, with a preference for the chocolate flavor, both worldwide as well as in Brazil (Associação Brasileira de Indústrias de Sorvetes, 2010).

Although vegan foods bring health benefits (Key et al., 2006; Spencer et al., 2003), they can contain high sugar, salts, and fat levels (Radnitz et al., 2015), with negative effects on humans' health. Therefore, studies to develop acceptable modified formulations are required, which can offer a pleasant experience for the consumer. In this context, sweeteners appear as an alternative to replace sucrose, considering the high sucrose content used in these formulations, including the ice cream, which can contain from 10 to $14 \%$ of sucrose (Goff, 2018) even in traditional formulations.

Time-intensity (TI) is a method widely used for temporal perception study when compared to other methodologies such as Temporal Dominance of Sensations (TDS) and Temporal Check All That Apply (TCATA) (Silva et al., 2018; Wu et al., 2019; Lima et al., 2020a; Harwood et al., 2020). In fact, TI brings information about the perception regarding the duration of the sensory attributes that can positively or 
negatively impact the final acceptance of the product, becoming an important tool for the evaluation of substitute ingredients (Lima et al., 2020b; Medeiros et al., 2020; Tavares Filho et al., 2020)

Therefore, the present study aimed to produce low-calorie chocolate-flavored frozen desserts with no addition of lactose and other animal-derived products and to evaluate the temporal profile and the consumers' preference of the samples.

\section{Materials and methods}

\subsection{Sampling}

Six frozen desserts formulations were made, free of lactose and other animal-derived ingredients, as follows: three soy protein-based formulations (S) and three rice protein-based formulations (R); sweetened with sucrose (SAC); sucralose (SUC); and steviol glycoside extract (STE). The ingredients and the respective concentrations are shown in Table 1.

Table 1. Ingredients and concentrations used in the manufacture of six chocolate-flavored frozen desserts formulations.

\begin{tabular}{|c|c|c|c|c|c|c|}
\hline \multirow{2}{*}{ Ingredients $(\% \mathrm{w} / \mathrm{w})$} & \multicolumn{6}{|c|}{ Formulations } \\
\hline & RSAC & RSUC & RSTE & SSAC & SSUC & SSTE \\
\hline Cassava starch & 8.50 & 8.50 & 8.50 & 8.50 & 8.50 & 8.50 \\
\hline Rice protein & 1.70 & 1.70 & 1.70 & - & - & - \\
\hline Soy protein & - & - & - & 1.70 & 1.70 & 1.70 \\
\hline Potable water & 55.15 & 55.15 & 55.15 & 55.15 & 55.15 & 55.15 \\
\hline Cocoa powder & 9.00 & 9.00 & 9.00 & 9.00 & 9.00 & 9.00 \\
\hline Cocoa butter & 7.00 & 7.00 & 7.00 & 7.00 & 7.00 & 7.00 \\
\hline Glucose & 3.00 & 3.00 & 3.00 & 3.00 & 3.00 & 3.00 \\
\hline Stabilizer & 0.40 & 0.40 & 0.40 & 0.40 & 0.40 & 0.40 \\
\hline Vanilla flavor & 0.15 & 0.15 & 0.15 & 0.15 & 0.15 & 0.15 \\
\hline Cocoa flavor & 0.10 & 0.10 & 0.10 & 0.10 & 0.10 & 0.10 \\
\hline Sucrose & 15.00 & - & - & 15.00 & - & - \\
\hline Inulin & - & 6.97 & 6.83 & - & 6.97 & 6.83 \\
\hline Maltodextrin & - & 8.00 & 8.00 & - & 8.00 & 8.00 \\
\hline Sucralose & - & 0.026 & - & - & 0.026 & - \\
\hline Stevia extract & - & - & 0.166 & - & - & 0.166 \\
\hline
\end{tabular}

Rice protein with sucrose (RSAC); Rice protein with sucralose (RSUC); Rice protein with steviol glycoside (RSTE); Soy protein with sucrose (SSAC); Soy protein with sucralose (SSUC); Soy protein with steviol glycoside (SSTE).

The following ingredients were used: cassava starch (Akio ${ }^{\circledR}$, São Paulo, Brazil); rice protein; soy protein; potable water; cocoa powder (Harald $\AA$, São Paulo, Brazil); cocoa butter (Barry Callebaut ${ }^{\circledR}$, São Paulo, Brazil); glucose (Arcolor ${ }^{\circledR}$, São Paulo, Brazil); stabilizer (Starmix premium, Kerry®, São Paulo, Brazil); vanilla flavor (Duas Rodas ${ }^{\circledR}$, Santa Catarina, Brazil); cocoa flavor (Duas Rodas ${ }^{\circledR}$, Santa Catarina, Brazil); sucrose (União®, São Paulo, Brazil); inulin (Orafti ${ }^{\circledR}$ HSI, Beneo Latino Americana Ltda., São Paulo, Brazil); maltodextrin; sucralose (Sweetmix ${ }^{\circledR}$, São Paulo, Brazil); and steviol glycoside extract (Rebaudioside A 97\%) (Steviafarma ${ }^{\circledR}$, Paraná, Brazil).

The ingredients were pre-homogenized and the mixture was pasteurized at $85^{\circ} \mathrm{C}$ for 25 minutes, cooled, and matured at $5{ }^{\circ} \mathrm{C}$ for 8 hours. After homogenization, the mixture was beaten in an ice maker (Cuisinart220V ICE-21) and the frozen desserts was stored in a freezer at $-18 \pm 2{ }^{\circ} \mathrm{C}$ (Medeiros et al., 2019). 


\subsection{Sensory evaluation}

The sensory evaluation was carried out at the Laboratory of Sensory Science and Consumer Research at State University of Campinas (Unicamp) - Brazil (Sensory Science and Consumer Research (LCSEC/UNICAMP), according to ISO 8589: 2007 (International Organization for Standardization, 2007). The samples were served $(8 \mathrm{~g})$ at $4 \pm 1{ }^{\circ} \mathrm{C}$, in a monadic sequential way and balanced complete blocks (Stone et al., 2012), in disposable $50 \mathrm{~mL}$ plastic cups, coded with three digits (Meilgaard et al., 2015) in an air-conditioned environment $\left(21 \pm 2{ }^{\circ} \mathrm{C}\right)$ and individual cabins. Potable water and cracker biscuits (Bauducco ${ }^{\circledR}$, Minas Gerais, Brazil) were served for palate cleansing.

Pre-tests were carried out to determine the ideal sucrose concentration and the sweetness equivalence of sweeteners related to sucrose (Medeiros et al., 2019).

\subsection{Training and selection of assessors for time-intensity analysis}

For the selection of the assessors, individuals were recruited from graduate students and staff from UNICAMP, interested in participating in the study, with at least one year experience in descriptive sensory analysis and ability to use a computer. Sixteen assessors were previously selected through the WALD sequential analysis (Meilgaard et al., 2015) using triangular tests. The assessors were trained in at least three sessions of approximately one hour each, for attribute recognition, the formation of sensory memory of the maximum and minimum references for each attribute, use of the software, and records of the sensations perceived with precision and reliability. The assessors were selected in accordance with ISO 8586: 2012, taking into account the repeatability ( $p$ of $\mathrm{F}_{\text {sample }}<0.50$ ) of the results and discrimination between samples $(p$ of $\mathrm{F}_{\text {repetition }}>0.05$ ), in addition to a consensus with the team (American Society for Testing and Materials, 2011; International Organization for Standardization, 2012, 2016). The maximum intensity references were milk chocolate (Nestlé $\AA$ ) for sweetness, semi-dark chocolate $($ Lacta $\AA)$ for the attributes bitter taste and chocolate flavor, and the maximum melting rate was considered as the total time for complete melting of the frozen desserts.

\subsection{Time-intensity analysis}

The TI profile was determined for the attributes sweet taste, bitter taste, chocolate flavor, and melting behavior, separately, according to the International Standard Guide for Time-Intensity Analysis (American Society for Testing and Materials, 2011). Data collection performed using the TI Analysis of Flavors and Tastes (TIAFT) (Bolini, 2012).

Twelve selected assessors evaluated the six samples $(8 \mathrm{~g})$ at $4 \pm 1{ }^{\circ} \mathrm{C}$ in three repetitions, and the intensity of each attribute was recorded as a function of the time, using a mouse in a $9 \mathrm{~cm}$ unstructured linear scale $(0$ $=$ none; 4.5 = moderate; $9=$ strong) (Cadena $\&$ Bolini, 2011). At the first warning issued by the computer, the assessor was instructed to place and keep the sample in the mouth, recording the attribute perceived; at the second beep, the assessor should swallow the sample, recording the attribute until the end of the perception, and the third beep indicated the end of the test.

The evaluation times for the attributes sweet taste, bitter taste, and chocolate flavor were 5 seconds of initial waiting, 15 seconds of residence in the mouth, and 60 seconds after ingestion. For the melting rate, the time of 5 seconds of initial waiting and 60 seconds of residence in the mouth was considered. The parameters of the TI curves were: the maximum intensity of the attribute $\left(\mathrm{I}_{\max }\right)$; the time to reach maximum intensity $\left(\mathrm{TI}_{\max }\right)$; the total area under the curve $\left(\mathrm{A}_{\mathrm{tot}}\right)$; and the total duration time of the attribute $\left(\mathrm{T}_{\mathrm{tot}}\right)$ (American Society for Testing and Materials, 2011). The results of the TI analysis were analyzed by Analysis of Variance (ANOVA), and Tukey's test $(p \leq 0.05)$, and the TI curves were constructed using the averages of the parameters as a function of time, for each sample in relation to each attribute. Data were analyzed using the software XLSTAT for Windows version 2012.5 (Addinsoft, Paris, France) 


\subsection{Acceptance tests}

For the acceptance test, 120 consumers (Hough et al., 2006), male and female aged between 18 and 60 years, representative of the target audience (Stone \& Sidel, 2004), evaluated the overall impression of the samples using a 9-cm unstructured linear hedonic scale, anchored at the ends by the terms "I disliked it very much" on the left, and "I liked it very much" on the right (Lawless \& Heymann, 2010). The purchase intention was assessed using a 5-point scale, ranging from "certainly not buy it" to "certainly buy it" (Meilgaard et al., 2015). The ideal intensities of the attributes sweet taste, chocolate flavor, and creaminess were also evaluated, using the Just-About-Right (JAR) scale with five (5) categories, being "much less than ideal", "less than ideal", "ideal", more than ideal" and "much more than ideal". The results were collected using the FIZZ Network Sensory software (version 2.47b - Biosystemes, Couternon, France). The averages were analyzed by ANOVA and Tukey's test $(p \leq 0.05)$, and the purchase intention was analyzed by frequency histograms. Data from the JAR scale were subjected to penalty analysis. Data from the overall impression were correlated with the parameters of the TI curves of sweetness, bitterness, chocolate flavor, and melting behavior, using Partial Least Squares (PLS) regression analysis. All data were analyzed with the aid of the program XLSTAT for Windows version 2012.5 (Addinsoft, Paris, France).

\section{Results and discussion}

\subsection{Time-intensity analysis (TI)}

The results obtained through ANOVA and Tukey's test are shown in Tables 2, 3, 4, and 5, and the TI curves are shown in Figure 1 for the attributes sweet taste, bitter taste, chocolate flavor, and melting behavior, respectively.

\subsubsection{Sweet taste}

Concerning the attribute sweet taste, no significant differences were observed between the formulations (Table 2) for the parameters Timax (Time to reach maximum intensity) and Ttot (Total time) $(p>0.05)$. For the maximum intensity (Imax) of this attribute, the sucralose-sweetened samples (RSUC and SSUC) showed the lowest values, and the soy protein-based sample (SSUC) differed from the soy protein-based sample sweetened with sucrose and stevia (SSAC and SSTE), whereas the sample RSUC was different only from SSAC. A similar result was found for the Area, also differing from the rice protein-based sample sweetened with steviol glycoside (RSTE).

Table 2. ANOVA and Tukey's test of Time-Intensity (TI) parameters for the sweet taste of the six chocolate-flavored frozen desserts formulations.

\begin{tabular}{|c|c|c|c|c|c|c|}
\hline Attributes & RSAC & RSUC & RSTE & SSAC & SSUC & SSTE \\
\hline Timax & $18.51^{\mathrm{a}}$ & $18.81^{\mathrm{a}}$ & $19.15^{\mathrm{a}}$ & $17.87^{\mathrm{a}}$ & $19.39^{a}$ & $18.00^{\mathrm{a}}$ \\
\hline Imax & $6.33^{\mathrm{abc}}$ & $5.97^{b c}$ & $6.66^{\mathrm{abc}}$ & $7.05^{\mathrm{ab}}$ & $5.72^{\mathrm{c}}$ & $7.37^{\mathrm{a}}$ \\
\hline Ttot & $36.08^{\mathrm{a}}$ & $36.82^{\mathrm{a}}$ & $40.36^{\mathrm{a}}$ & $37.42^{\mathrm{a}}$ & $33.73^{\mathrm{a}}$ & $37.13^{a}$ \\
\hline Area & $118.16^{\mathrm{abc}}$ & $109.36^{b c}$ & $142.87^{\mathrm{a}}$ & $135.78^{\mathrm{ab}}$ & $98.55^{c}$ & 149.18 \\
\hline
\end{tabular}

Rice protein with sucrose (RSAC); Rice protein with sucralose (RSUC); Rice protein with steviol glycoside (RSTE); Soy protein with sucrose (SSAC); Soy protein with sucralose (SSUC); Soy protein with steviol glycoside (SSTE). Averages with the same letter on the same line do not present a significant difference at $p \leq 0.05$.

\subsubsection{Bitter taste}

Significant differences were observed for the time to reach the maximum intensity of the bitter taste only between RSTE and SSAC (Table 3), and the soy protein-based sample sweetened with sucrose showed the shortest time. The stevia-sweetened samples (RSTE and SSTE) showed higher values for maximum intensity 
(Imax), total duration (Ttot), and Area under the curve (Area), whereas the sucralose-sweetened samples showed the lowest values, with significant differences between them $(p \leq 0.05)$. The soy protein-based sample sweetened with sucrose (SSAC) was different from the stevia-sweetened samples (RSTE and SSTE) and similar to the rice protein-based sample sweetened with sucrose (RSAC), which differed from the sucralose-sweetened samples (RSUC and SSUC). Although the bitter taste is correlated with the use of steviol glycoside (Peres et al., 2018; Freitas et al., 2016; Voorpostel et al., 2014; Cadena et al., 2013), the bitter taste of the samples of this study may be due to the natural bitterness of the cocoa powder used in the formulations.

Table 3. ANOVA and Tukey's test of Time-Intensity (TI) parameters for the bitter taste of the six chocolate-flavored frozen desserts formulations.

\begin{tabular}{ccccccc}
\hline Attributes & RSAC & RSUC & RSTE & SSAC & SSUC & SSTE \\
\hline Timax & $16.95^{\mathrm{ab}}$ & $16.91^{\mathrm{ab}}$ & $19.14^{\mathrm{a}}$ & $15.92^{\mathrm{b}}$ & $17.19^{\mathrm{ab}}$ & $17.99^{\mathrm{ab}}$ \\
\hline Imax & $7.02^{\mathrm{bc}}$ & $5.72^{\mathrm{d}}$ & $8.01^{\mathrm{a}}$ & $6.36^{\mathrm{cd}}$ & $5.50^{\mathrm{d}}$ & $7.70^{\mathrm{ab}}$ \\
\hline Ttot & $32.34^{\mathrm{ab}}$ & $28.32^{\mathrm{b}}$ & $36.84^{\mathrm{a}}$ & $30.32^{\mathrm{b}}$ & $28.08^{\mathrm{b}}$ & $37.93^{\mathrm{a}}$ \\
\hline Area & $137.20^{\mathrm{ab}}$ & $97.77^{\mathrm{c}}$ & $166.09^{\mathrm{a}}$ & $111.38^{\mathrm{bc}}$ & $101.24^{\mathrm{c}}$ & $165.47^{\mathrm{a}}$ \\
\hline
\end{tabular}

Rice protein with sucrose (RSAC); Rice protein with sucralose (RSUC); Rice protein with steviol glycoside (RSTE); Soy protein with sucrose (SSAC); Soy protein with sucralose (SSUC); Soy protein with steviol glycoside (SSTE). Averages with the same letter on the same line do not present a significant difference at $p \leq 0.05$.

\subsubsection{Chocolate flavor}

No differences were observed among the samples $(p \leq 0.05)$ for the parameters Timax and Ttot of the chocolate flavor (Table 4). However, the sucralose-sweetened samples (RSUC and SSUC) showed the lowest intensities of this attribute, not differing from the soy protein-based sample sweetened with steviol glycoside (RSTE). Regarding the attribute Area, the sample RSTE had a higher average, differing from the sucralosesweetened samples (RSUC and SSUC).

Table 4. ANOVA and Tukey's test of the Time-Intensity (TI) parameters for the chocolate flavor of the six chocolateflavored frozen desserts formulations.

\begin{tabular}{ccccccc}
\hline Attributes & RSAC & RSUC & RSTE & SSAC & SSUC & SSTE \\
\hline Timax & $16.21^{\mathrm{a}}$ & $16.82^{\mathrm{a}}$ & $16.62^{\mathrm{a}}$ & $16.31^{\mathrm{a}}$ & $16.96^{\mathrm{a}}$ & $17.94^{\mathrm{a}}$ \\
\hline Imax & $6.66^{\mathrm{a}}$ & $5.23^{\mathrm{b}}$ & $6.02^{\mathrm{ab}}$ & $6.39^{\mathrm{a}}$ & $5.01^{\mathrm{b}}$ & $6.41^{\mathrm{a}}$ \\
\hline Ttot & $27.82^{\mathrm{a}}$ & $23.83^{\mathrm{a}}$ & $28.20^{\mathrm{a}}$ & $27.59^{\mathrm{a}}$ & $25.98^{\mathrm{a}}$ & $29.71^{\mathrm{a}}$ \\
\hline Area & $114.21^{\mathrm{ab}}$ & $90.05^{\mathrm{bc}}$ & $110.71^{\mathrm{ab}}$ & $106.98^{\mathrm{ab}}$ & $80.51^{\mathrm{c}}$ & $116.44^{\mathrm{a}}$ \\
\hline
\end{tabular}

Rice protein with sucrose (RSAC); Rice protein with sucralose (RSUC); Rice protein with steviol glycoside (RSTE); Soy protein with sucrose (SSAC); Soy protein with sucralose (SSUC); Soy protein with steviol glycoside (SSTE). Averages with the same letter on the same line do not present a significant difference at $p \leq 0.05$.

\subsubsection{Melting behavior}

The samples differed significantly $(p \leq 0.05)$ only for the total melting time, and the samples made with sucrose substitution (RSUC, RSTE, SSUC, and SSTE) showed a longer time for a complete melt, not differing from each other, with significant differences from the sucrose-sweetened samples (RSAC and SSAC) (Table 5). The use of inulin and maltodextrin as body agents to replace sucrose may have prolonged the melting time (Góral et al., 2018).

Table 5. ANOVA and Tukey's test of Time-Intensity (TI) parameters for melting of the six chocolate-flavored ice cream formulations.

\begin{tabular}{ccccccc}
\hline Attributes & RSAC & RSUC & RSTE & SSAC & SSUC & SSTE \\
\hline Ttot & $19.83^{\mathrm{c}}$ & $23.70^{\mathrm{ab}}$ & $25.53^{\mathrm{a}}$ & $20.49^{\mathrm{c}}$ & $24.95^{\mathrm{a}}$ & $24.10^{\mathrm{ab}}$ \\
\hline Area & $100.83^{\mathrm{a}}$ & $88.43^{\mathrm{a}}$ & $98.13^{\mathrm{a}}$ & $79.90^{\mathrm{a}}$ & $95.93^{\mathrm{a}}$ & $92.85^{\mathrm{a}}$ \\
\hline
\end{tabular}

Rice protein with sucrose (RSAC); Rice protein with sucralose (RSUC); Rice protein with steviol glycoside (RSTE); Soy protein with sucrose (SSAC); Soy protein with sucralose (SSUC); Soy protein with steviol glycoside (SSTE). Averages with the same letter on the same line do not present a significant difference at $p \leq 0.05$. 

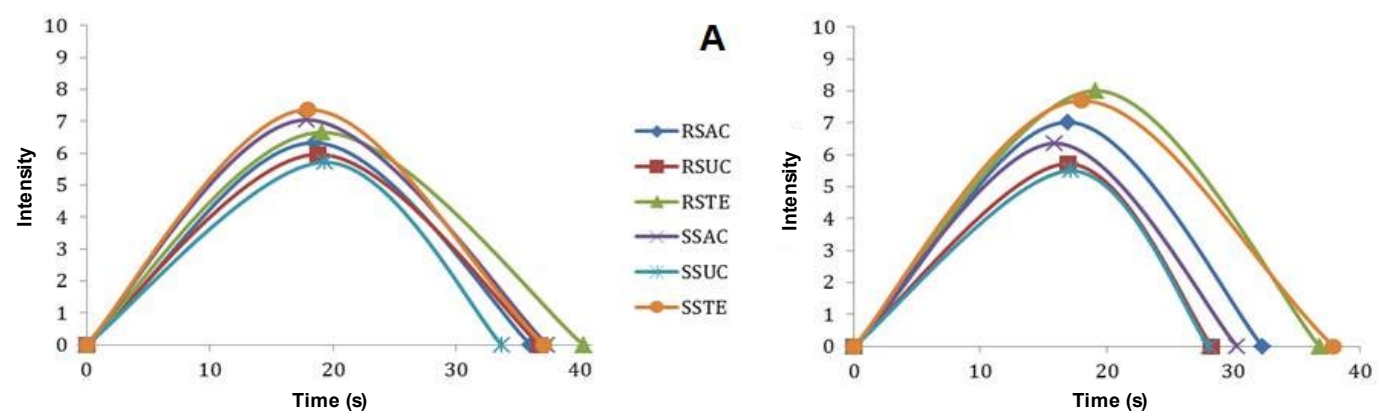

B
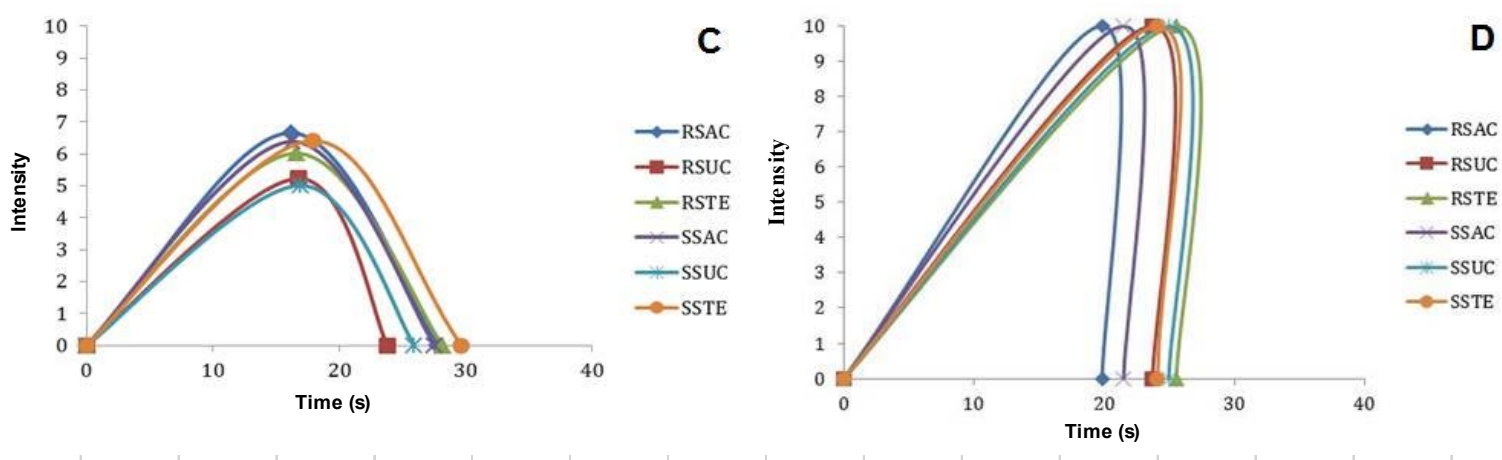

Figure 1. Time-intensity (TI) curve for the attributes sweet taste (A), bitter taste (B), chocolate flavor (C), and melting (D) of the six chocolate-flavored frozen desserts formulations.

\subsection{Acceptance test}

The results of the acceptance test analyzed by ANOVA and Tukey's test $(p \leq 0.05)$ for the overall impression are shown in Table 6, and the internal preference map is shown in Figure 2. The principal components 1 and 2 explained $52.13 \%$ of the variance for the acceptance of the samples, indicating a clear division between consumers.

Table 6. ANOVA and Tukey's test for the overall impression of the six chocolate-flavored frozen desserts formulations.

\begin{tabular}{cccccccc}
\hline & RSAC & RSUC & RSTE & SSAC & SSUC & SSTE & MSD \\
\hline $\begin{array}{c}\text { Overall } \\
\text { impression }\end{array}$ & $6.17^{\mathrm{a}}$ & $5.51^{\mathrm{bc}}$ & $5.42^{\mathrm{c}}$ & $7.30^{\mathrm{a}}$ & $5.62^{\mathrm{bc}}$ & $5.76^{\mathrm{bc}}$ & 0.67 \\
\hline
\end{tabular}

Rice protein with sucrose (RSAC); Rice protein with sucralose (RSUC); Rice protein with steviol glycoside (RSTE); Soy protein with sucrose (SSAC); Soy protein with sucralose (SSUC); Soy protein with steviol glycoside (SSTE); Minimum significant difference (MSD). Averages with the same letter on the same line do not present a significant difference at $p \leq 0.05$.

The sucrose-sweetened samples were the most preferred, differing $(p \geq 0.05)$ from the samples sweetened with sweeteners, which showed lower acceptance, with scores above 4.5 (indifference) considering the hedonic scale from 0 to $9 \mathrm{~cm}$. This result can be seen in Figure 2, which showed that the SSAC and RSAC were positioned close to most consumers (represented by red dots), whereas the other samples were located on the opposite side, far from most consumers. 


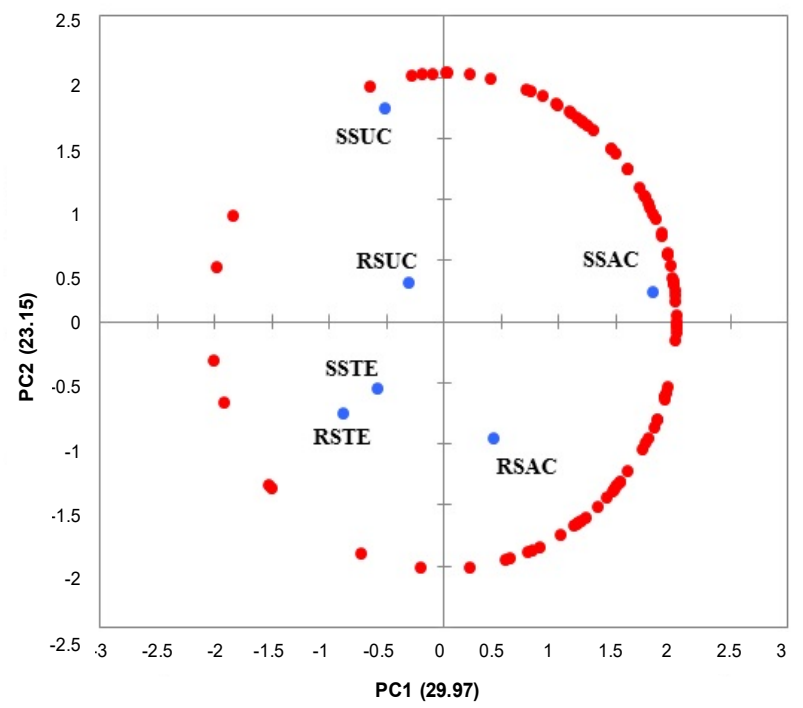

Figure 2. Internal preference map $(\mathrm{PC} 1 \times \mathrm{PC} 2: 53.12 \%)$.

\subsection{Purchase intention}

The purchase intention was analyzed using histograms with the distribution of responses of the consumers in the acceptance test of the chocolate-flavored frozen desserts (Figure 3).

The sucrose-sweetened samples (RSAC and SSAC) showed positive purchase intent, with $57 \%$ of consumers showing interest in buying ("certainly would buy it" and "probably would buy it") the rice protein-based sample (RSAC), and $80 \%$ in buying the soy protein-based sample (SSAC). The rice protein-based samples sweetened with sucralose (RSUC) and stevia (RSTE) had a greater number of undecided consumers, 30 and $31 \%$ respectively, with a similar number of consumers with positive (35 and $32 \%$, respectively) and negative intentions (32 and 38\%, respectively). The soy protein-based samples sweetened with sucralose (SSUC) and stevia (SSTE) showed a greater distribution throughout the five points of the scale, with an emphasis for SSUC and SSTE in the responses "probably would buy it" (30\%) and "I probably would not buy it" (26\%), respectively.

These data corroborate with the results found in the overall impression, in which the sucrose-sweetened samples were more preferred, and the soy protein-based sample (SSAC) presented the higher scores, with no significant differences $(p \geq 0.05)$ from RSAC. This greater purchase intention for the soy protein-based formulation may be due to the familiarization of vegan consumers with soy-based products.

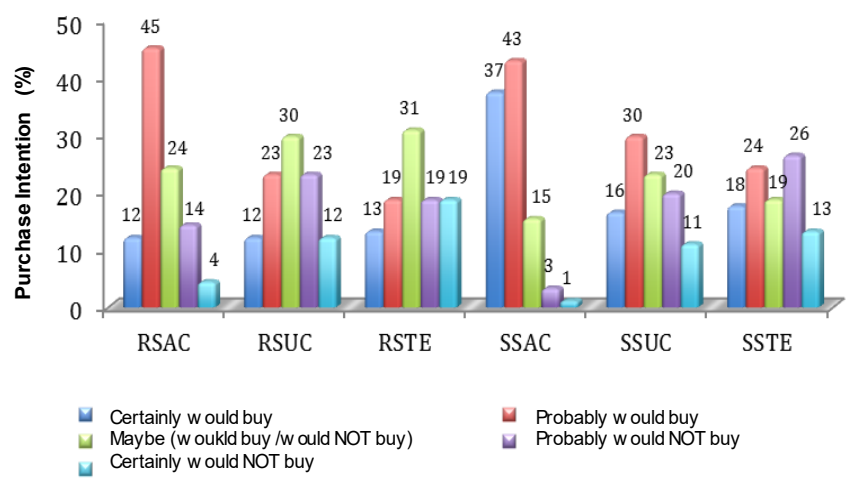

Figure 3. Distribution histograms of the consumers' purchase intention of chocolate-flavored frozen desserts formulations. 


\subsection{Penalty analysis}

The penalty analysis allowed correlating the results from the JAR scale and the overall impression, evaluating the attributes that hindered the consumers' acceptance, corresponding to the lowest scores of the acceptance test (Laguna et al., 2013). The JAR scale was divided into three categories as following: "less than ideal" (1-2); "ideal" (3); and "more than ideal" (4-5), and the percentage of consumers who scored in each category was calculated for each sample (Palazzo \& Bolini, 2017). Figure 4 shows the penalties analysis graph, representing the percentages of consumers (x-axis) as a function of the penalties (y-axis) of each attribute (sweet taste, creaminess, and chocolate flavor). The attribute was considered significant when selected by at least $20 \%$ of consumers (Laguna et al., 2013).

In general, the chocolate flavor impaired the consumers' preference when the intensity was below the ideal, and $36.63 \%$ of consumers reported this characteristic for the formulations with the lower acceptance scores. Concerning the sweet taste, a lower consumers' preference was observed for the formulations with scores above the ideal sweetness, which was reported by $20.14 \%$ of consumers.

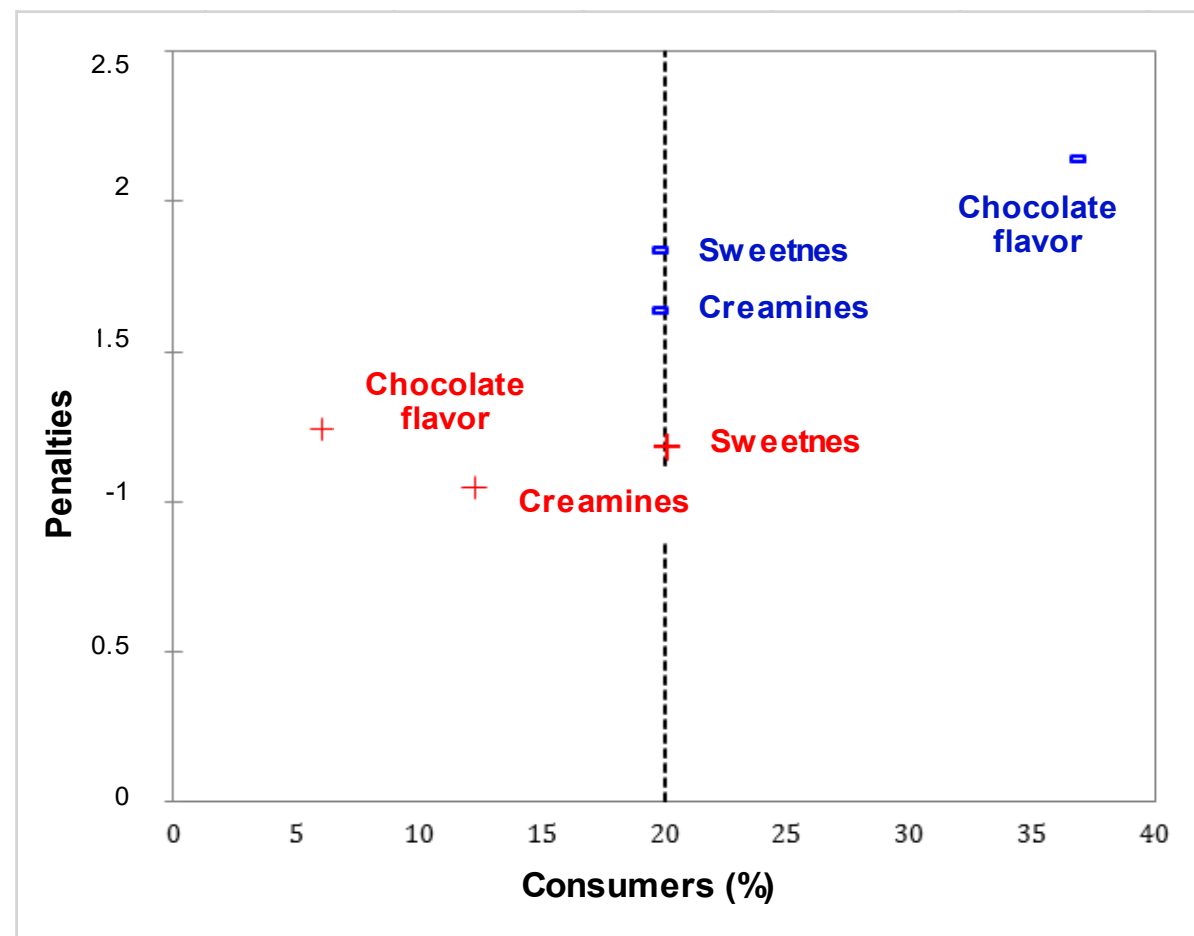

Figure 4. Penalties analysis graph of the attributes creaminess, sweetness, and chocolate flavor for the overall impression evaluated by 120 consumers. Cutoff point: $20 \%$ of consumers.

\subsection{Temporal drivers of linking}

The results obtained in the TI analysis were correlated with the overall impression, using the multivariate statistics partial least squares regression (PLS), aimed to obtain the drivers of liking of the plant-based frozen desserts formulations. The overall impression was considered as the dependent variable, and the TI parameters were associated with the independent variables.

The parameters of the TI curves (TImax) of sweetness, bitterness, and chocolate flavor (orange color bars in Figure 5) contributed negatively to the consumers' acceptance. The longer the time to start the perception of maximum sweetness, bitterness, and chocolate flavor, lower the overall impression. 


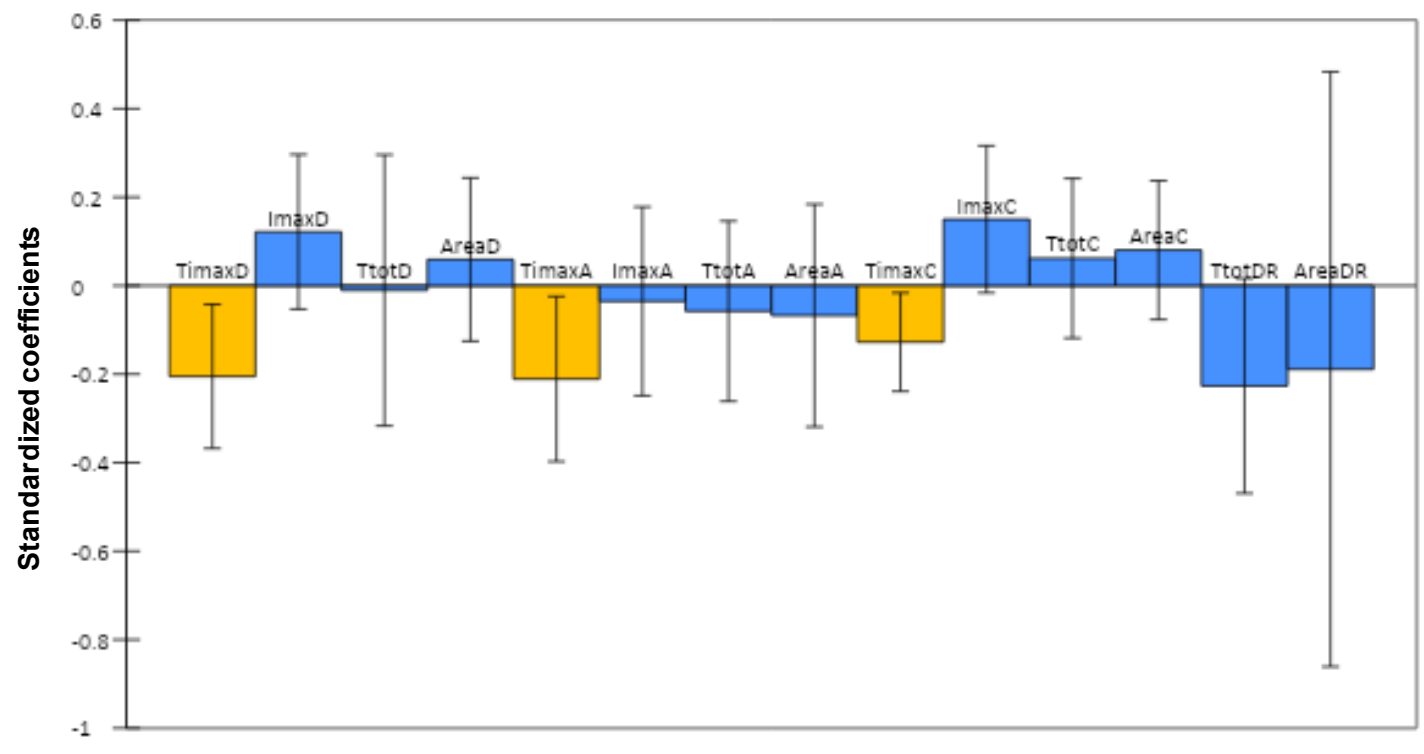

Figure 5. Partial least squares regression analysis of the Time-Intensity (TI) curves for sweetness, bitterness, chocolate flavor, and melting behavior of the samples, and the overall impression by consumers.

\section{Conclusion}

No significant differences $(p \leq 0.05)$ were observed in the temporal profile of the plant-protein based frozen desserts.

The use of sweeteners provided changes in the formulations, and the replacement of sucrose by sucralose provided a lower intensity of sweetness, bitterness, and chocolate flavor of the frozen desserts, whereas the stevia-sweetened formulations showed greater intensity and duration of the bitter taste. The use of body agents directly affected the texture of the frozen desserts, prolonging the melting time in the mouth. The use of sweeteners had a negative impact on the consumers' acceptance, and the samples were characterized by presenting a less intense chocolate flavor and sweetness higher than ideal.

Although all samples showed satisfactory acceptance, only the sucrose-sweetened samples exhibited a positive purchase intention. Further studies are needed to optimize and improve low-calorie vegan formulations.

\section{Acknowledgements}

This study was carried out with the support of the Coordination for the Improvement of Higher Education Personnel - Brazil (Coordenação de Aperfeiçoamento de Pessoal de Nível Superior (CAPES)) - Financing Code 001 .

\section{References}

Aboulfazli, F., Shori, A. B., \& Baba, A. S. (2016). Effects of the replacement of cow milk with vegetable milk on probiotics and nutritional profile of fermented ice cream. Food Science and Technology, 70, 261-270. http://dx.doi.org/10.1016/j.Iwt.2016.02.056

American Society for Testing and Materials - ASTM International. (2011). ASTM E1909-11: Standard guide for time-intensity evaluation of sensory attributes. West Conshohocken: ASTM International.

Associação Brasileira de Indústrias de Sorvetes - ABIS. (2010). Brasil é o $10^{\circ}$ em consumo de sorvetes. Retrieved in 2018 , May 15, from http://www.abis.com.br

Assumpção, G. M. P. (2008). Viabilidade tecnológica do uso de extrato hidrossolúvel de soja na fabricação de iogurte (Dissertação de mestrado). Universidade Federal de Lavras, Lavras. 
Bolini, H. M. A. (2012). Time-Intensity Analysis of Flavors and Tates - TIAFT: software. Registro $n^{\circ}$ 12445-5, 03 jan. 2012,27 mar. 2012. Revista da Propriedade Industrial, (2151), 178.

Cadena, R. S., \& Bolini, H. M. A. (2011). Time-intensity analysis and acceptance test for traditional and light vanilla ice cream. Food Research International, 44(3), 677-683. http://dx.doi.org/10.1016/j.foodres.2010.12.012

Cadena, R. S., Cruz, A. G., Netto, R. R., Castro, W. F., Faria, J., \& Bolini, H. M. A. (2013). Sensory profile and physicochemical characteristics of mango nectar sweetened with high intensity sweeteners throughout storage time. Food Research International, 54(2), 1670-1679. http://dx.doi.org/10.1016/j.foodres.2013.10.012

Casé, F., Deliza, R., Rosenthal, A., Mantovani, D., \& Felberg, I. (2005). Produção de 'leite' de soja enriquecido com cálcio. Food Science and Technology, 25(1), 86-91. http://dx.doi.org/10.1590/S0101-20612005000100014

Craig, W. J. A. N. D., \& Mangels, A. R. (2016). Position of the American Dietetic Association: Vegetarian diets. Journal of the Academy of Nutrition and Dietetics, 116(12), 1970-1980. PMid:27886704. http://dx.doi.org/10.1016/j.jand.2016.09.025

Cramer, H., Kessler, C. S., Sundberg, T., Leach, M. J., Schumann, D., Adams, J., \& Lauche, R. (2017). Characteristics of Americans Choosing Vegetarian and Vegan Diets for Health Reasons. Journal of Nutrition Education and Behavior, 49(7), 561 567. PMid:28689610. http://dx.doi.org/10.1016/j.jneb.2017.04.011

Crizel, T. M., Araujo, R. R., Rios, A. O., Rech, R., \& Flôres, S. H. (2014). Orange fiber as a novel fat replacer in lemon ice cream. Food Science and Technology, 34(2), 332-340. http://dx.doi.org/10.1590/fst.2014.0057

Cruz, A. G., Antunes, A. E. C., Sousa, A., Faria, J. A. F., \& Saad, S. M. I. (2009). Ice-cream as a probiotic food carrier. Food Research International, 42(9), 1233-1239. http://dx.doi.org/10.1016/j.foodres.2009.03.020

Dyett, P. A., Sabate, J., Haddad, E., Rajaram, S., \& Shavlik, D. (2013). Vegan lifestyle behaviors: An exploration of congruence with health-related beliefs and assessed health indices. Appetite, 67(0), 119-124. PMid:23583444. http://dx.doi.org/10.1016/j.appet.2013.03.015

Fox, N., \& Ward, K. (2008). Health ethics and environment: A qualitative study of vegetarian motivations. Appetite, 50(2-3), 422429. PMid:17980457. http://dx.doi.org/10.1016/j.appet.2007.09.007

Freitas, M. L. F., Dutra, M. B. D. L., \& Bolini, H. M. A. (2016). Sensory profile and acceptability for pitanga (Eugenia uniflora L.) nectar with different sweeteners. Food Science \& Technology International, 22(8), 720-731. PMid:27118767. http://dx.doi.org/10.1177/1082013215607077

Góral, M., Kozłowicz, K., Pankiewicz, U., Góral, D., Kluza, F., \& Wójtowicz, A. (2018). Impact of stabilizers on the freezing process, and physicochemical and organoleptic properties of coconut milk-based ice cream. LWT, 92, 516-522. https://doi.org/10.1016/j.Iwt.2018.03.010

Goff, H. D. (2018). Ice cream and frozen desserts: Product types. In G. W. Smithers (Ed.), Reference module in food science. Oxford: Elsevier.

Hagenimana, A., Ding, X., \& Gu, Y. (2007). Steady state flow behaviours of extruded blend of rice flour and soy protein concentrate. Food Chemistry, 101(1), 241-247. http://dx.doi.org/10.1016/j.foodchem.2006.01.043

Harwood, S., Parker, M. N., \& Drake, M. A. (2020). Influence of ethanol concentration on sensory perception of rums using temporal check-all-that-apply. Journal of Sensory Studies, 35(1), e12546. http://dx.doi.org/10.1111/joss.12546

Hough, G., Wakeling, I., Mucci, A., Chambers 4th, E., Gallardo, I. M., \& Alves, L. R. (2006). Number of consumers necessary for sensory acceptability tests. Food Quality and Preference, 17(6), 522-526. http://dx.doi.org/10.1016/j.foodqual.2005.07.002 International Organization for Standardization - ISO. (2007). ISO 8589:2007: Sensory analysis - General guidance for the design of test rooms. Geneva: ISO.

International Organization for Standardization - ISO. (2012). ISO 8586-1:2012: Sensory analysis: General guidelines for the selection, training and monitoring of selected assessors and expert sensory assessors. Geneva: ISO.

International Organization for Standardization - ISO. (2016). ISO 13299:2016(E): Sensory analysis: Methodology: General guidance for establishing a sensory profile. Geneva: ISO.

Key, T. J., Appleby, P. N., \& Rosell, M. S. (2006). Health effects of vegetarian and vegan diets. The Proceedings of the Nutrition Society, 65(1), 35-41. PMid:16441942. http://dx.doi.org/10.1079/PNS2005481

Laguna, L., Varela, P., Salvador, A., \& Fiszman, S. (2013). A new sensory tool to analyze the oral trajectory of biscuits with different fat and fibre contents. Food Research International, 51, 544-553. https://doi.org/10.1016/j.foodres.2013.01.003.

Lawless, H. T., \& Heymann, H. (2010). Sensory evaluation of food: Principles and practices (2nd ed.). New York: Springer Verlag. http://dx.doi.org/10.1007/978-1-4419-6488-5

Lima, R. S., Medeiros, A. C., \& Bolini, H. M. A. (2020a). Does the indoor thermal environment influence the dominant sensation in a functional beverage attributes? Journal of Food Science, 85(10), 3536-3542. PMid:32885431.

http://dx.doi.org/10.1111/1750-3841.15427

Lima, R. S., Medeiros, A. C., \& Bolini, H. M. A. (2020b). Sucrose replacement: A sensory profile and time-intensity analysis of a tamarind functional beverage with artificial and natural non-nutritive sweeteners. Journal of the Science of Food and Agriculture, 101(02), 593-602. PMid:32683712. http://dx.doi.org/10.1002/jsfa.10671

Medeiros, A. C., Tavares Filho, E. R., \& Bolini, H. M. A. (2019). Impact of natural and artificial sweeteners compounds in the sensory profile and preference drivers applied to traditional, lactose-free, and vegan frozen desserts of chocolate Flavor. Journal of Food Science, 84(10), 2973-2982. PMid:31546291. http://dx.doi.org/10.1111/1750-3841.14806 
Medeiros, A. C., Tavares Filho, E. R., \& Bolini, H. M. A. (2020). Temporal profile of low-calorie lactose-free ice cream chocolate flavor: Temporal dominance sensation and multiple time-intensity analysis. Journal of Food Science and Technology, 58(8), 3164-3173. PMid:34294978. http://dx.doi.org/10.1007/s13197-020-04819-2

Meilgaard, M. C., Civille, G. V., \& Carr, B. T. (2015). Sensory evaluation techniques (5th ed.). London: Taylor \& Francis.

Miyamoto, A. B., \& Auler, F. (2008). Análise da preferência de preparações com derivados de soja e leite de vaca, na cidade de Maringá/PR. Ciência, Cuidado e Saúde, 7(1), 18-25.

Palazzo, A. B., \& Bolini, H. M. A. (2017). Sweeteners in diet chocolate ice cream: Penalty analysis and acceptance evaluation. Journal of Food Studies, 6(1), 1-13. http://dx.doi.org/10.5296/jfs.v6i1.10655

Peres, J., Esmerino, E., Da Silva, A. L., Racowski, I., \& Bolini, H. (2018). Sensory profile, drivers of liking, and influence of information on the acceptance of low-calorie synbiotic and probiotic chocolate ice cream. Journal of Food Science, 83(5), 13501359. PMid:29660810. http://dx.doi.org/10.1111/1750-3841.14120

Radnitz, C., Beezhold, B., \& Dimatteo, J. (2015). Investigation of lifestyle choices of individuals following a vegan diet for health and ethical reasons. Appetite, 90, 31-36. PMid:25725486. http://dx.doi.org/10.1016/j.appet.2015.02.026

Ruby, M. B. (2012). Vegetarianism: A blossoming field of study. Appetite, 58(1), 141-150. PMid:22001025. http://dx.doi.org/10.1016/j.appet.2011.09.019

Silva, H. L. A., Balthazar, C. F., Silva, R., Vieira, A. H., Costa, R. G. B., Esmerino, E. A., Freitas, M. Q., \& Cruz, A. G. (2018). Sodium reduction and flavor enhancer addition in probiotic prato cheese: Contributions of quantitative descriptive analysis and temporal dominance of sensations for sensory profiling. Journal of Dairy Science, 101(10), 8837-8846. PMid:30077456. http://dx.doi.org/10.3168/jds.2018-14819

Spencer, E. A., Appleby, P. N., Davey, G. K. E., \& Key, T. J. (2003). Diet and body mass index in 38000 epic-Oxford meateaters, fish-eaters, vegetarians and vegans. International Journal of Obesity and Related Metabolic Disorders, 27(6), 728-734. PMid:12833118. http://dx.doi.org/10.1038/sj.ijo.0802300

Stone, H., \& Sidel, J. L. (2004). Sensory evaluation practices. New York: Academic Press.

Stone, H., Bleibaum, R. N., \& Thomas, H. A. (2012). Sensory evaluation practices (4th ed.). New York: Academic Press.

Tavares Filho, E. R., Esmerino, E. A., Santos-Junior, V. A., Lins da Silva, C. M. A., \& Bolini, H. M. A. (2020). Dynamic aspects of salt reduction in tomato sauce by use of flavor enhancers and a bitter blocker. Food Science \& Technology International, 26(6), 549-559. PMid:32228101. http://dx.doi.org/10.1177/1082013220913361

Tseng, Y. C., Xiong, Y. L., \& Yang, F. (2009). Influence of inulin/oligofructose on the acid-induced cold aggregation and gelation of preheated soy proteins. Journal of the Science of Food and Agriculture, 89(15), 2650-2658. http://dx.doi.org/10.1002/jsfa.3770

Voorpostel, C. R., Dutra, M. B. D. E. L., \& Bolini, H. M. A. (2014). Sensory profile and drivers of liking for grape nectar among smoker and nonsmoker consumers. Food Science and Technology, 34(1), 164-173. http://dx.doi.org/10.1590/S010120612014000100024

Wu, A. Z., Lee, R. W., Calvé, L. B., \& Cayeux, I. (2019). Temporal profiling of simplified lemonade using temporal dominance of sensations and temporal check-all-that-apply. Journal of Sensory Studies, 34(1), e12531. http://dx.doi.org/10.1111/joss.12531

Funding: Coordenação de Aperfeiçoamento de Pessoal de Nível Superior/CAPES - Financing Code 001. 